\title{
THE ROLE OF LISTING PRICE STRATEGIES ON THE PROBABILITY OF SELLING A HOUSE: EVIDENCE FROM VIETNAM1
}

\author{
Hong Nguyen Thi Bich \\ Faculty of Economics \\ University of Economics Ho Chi Minh City \\ e-mail:hongntb@ueh.edu.vn \\ Hoai Nguyen Trong \\ Faculty of Economics \\ University of Economics Ho Chi Minh City \\ e-mail:hoaianh@ueh.edu.vn \\ Hiep Truong Thanh \\ Faculty of Economics \\ University of Economics Ho Chi Minh City \\ e-mail:hieptt@ueh.edu.vn
}

\section{Abstract}

The aim of this paper is to measure the dynamic effects of listing price strategies and housing features on the probability of selling a house over the marketing period by adopting a two-stage regression analysis. In the first stage, we define the listing price strategies as the gaps between the actual listing price and expected selling price, estimated by a hedonic model. The Cox Probability Hazard models are applied in the second stage to measure the effects of listing price strategies on the probability of sales over various listing periods, such as 30-day, 90-day, 180-day and 270-day listing periods.

We find that overpriced listing strategies have a significant impact on the probability of sale at any point during the first 30 days of marketing time. This effect seems to diminish and disappear after six months of marketing time. This shows that the first 30 days of the marketing time are critical and housing liquidity is strongly affected by pricing strategies. When the time on market is over 30 days, the influence of the seller's pricing decisions on housing liquidity is diminished.

Key words: Vietnam Housing Market, Listing Price Strategies, Probability of Sale, Cox Proportional Hazard Model.

JEL Classification: C51, D01, R21.

Citation: Nguyen, H.T.B, Nguyen, H.T., Truong, H.T. (2020). The role of listing price strategies on the probability of selling a house: evidence from Vietnam. Real Estate Management and Valuation, 28(2), 6375.

DOI: https:/ / doi.org/10.1515/remav-2020-0016

\section{Introduction}

A house is typically the largest single asset in a household's portfolio, and housing as a whole is a

\footnotetext{
${ }^{1}$ The authors would especially like to thank Norman Miller and Pham Khanh Nam for their help and advice during the development of this manuscript.
} 
significant fraction of total wealth (Tracy \& Schneider, 2001). The housing market is thus highly significant, not only to households but also to the macro-economy. Other financial assets, such as stocks or bonds, are much more homogeneous and traded in large volumes within seconds. In contrast, a housing transaction process is much slower and more complex, often taking several months to complete, because of the heterogeneous and illiquid nature of real estate assets. Aside from the sale price, housing liquidity is also a major concern for home sellers (Bhuiyan \& Hasan, 2016).

A general understanding of the current liquidity conditions in real estate markets, which are determined by the individual preferences of house buyers and the expectations of house sellers, is essential for market players. Liquidity is a concern for home sellers, real estate institutional investors, mortgage lenders and supporting government agencies, as it affects the riskiness of owning or lending housing assets. (Cajias \& Freudenreich, 2018).

To capture the degree of housing illiquidity, several papers have focused on measuring the time on the market (TOM) as an indication of liquidity. (Jud, et al., 1996). These studies are all focused on identifying factors, such as housing features, that influence the time on the market of a house (Johnson, et al., 2008; Benefield, et al., 2014), especially the typical characteristics of the house compared to other houses in the local market (Haurin, 1988; Jud, et al., 1996; Glower, et al., 1998; Ong \& Koh, 2000; Harding, et al., 2003; Li, 2004). Demand-side and supply-side factors of housing market conditions (Yang \& Yavas, 1995; Anglin, et al., 2003) are also important determinants of the marketing time of a house. Other idiosyncratic elements influencing the time on the market refer to the seller's motivation (Anglin, et.al., 2003; Johnson, et. al., 2008) and the impact of real estate brokers (Elder, et al., 2000; Turnbull \& Dombrow 2007; Levitt \& Syverson, 2008). Time on the market has been criticized as a measure of liquidity as homes that are listed and not sold are missing from the sample. Time on the market has also been criticized as being manipulated by brokers that take a home off the market briefly and then re-list it, claiming it as a new listing. Such strategies contaminate the TOM data.

However, other approaches for measuring liquidity are possible. We can define liquidity as "the inverse of the amount of time that elapses between the decision to sell an asset and the receipt of the full market value by the seller" (Wood \& Wood, 1985). Kluger and Miller (1990) introduced a new measure of housing liquidity related to the relative odds ratio, interpreted as the relative probability of sale between an interesting house and a "typical house" at a particular instance in time. This liquidity measurement was then applied by several studies (Glower, et al., 1998; Mcgreal, et al., 2009, Hui, et.al., 2012; Haurin, et al., 2013; Cirman, et.al., 2015). In this study, we measure the liquidity of houses based on this method. This means that, instead of examining the expected time on the market of a house, our measure is the probability of selling a house within a given time frame.

The aim of the study is to explore the dynamic effects of listing price strategies and housing features on the probability of selling a house over various listing periods, such as 30-day, 90-day, 180day and 270-day listing periods. In this way, we can pick up the non-linear nuances of liquidity strategies over the typical period over which homes are marketed. The results may serve as a guide for policymakers to conduct a liquidity analysis on the housing market in Vietnam or others. Especially for home sellers and agents, an understanding of the dynamic effect of listing strategies and home features on the housing liquidity is very helpful in determining what they can do to help speed up the selling process, if that is a greater priority than price. These strategies could include applying a reasonable pricing strategy or refurbishing some features that have an impact on the aggregate volume of potential buyers (Bhuiyan \& Hasan, 2016).

The study is organized into five sections. Following this introduction, the second section provides a brief literature review on the listing price and marketing time relationship. The third section presents the theoretical framework of the semi-parametric Cox Proportional Hazard model. The fourth section describes the study methodology and the data source. The fifth section presents the empirical results, with the last section presenting the conclusions and summarizing the study.

\section{Literature review}

The selling process of a house starts when a home seller chooses a listing price seen by a flow of potential buyers, some of whom are interested and inspect the house, and a few who may want to buy it (Dubé \& Legros, 2016). According to searching theories, a buyer, who wants to buy the house, will offer a bid price and engage in a negotiation process with the seller for a matching that determines the transaction price high or low depending on the relative bargaining power of the buyer and the seller (Dubé \& Legros, 2016). In this process, the buyer is rather isolated, possessing different levels of 
information, relying on different sources of information, so each potential buyer will value the house differently. Therefore, the seller chooses his listing price first without knowing the reservation price of the potential buyers. The listing price serves two different functions, one sends a signal to the buyers about the reservation price of the seller, another is perceived as the price the seller will accept immediately (Yavas \& Yang, 1995). Thus, the listing price places an upper limit on the bid prices of the buyers and the final transaction price (Haurin, et al., 2013). This means that the chosen listing price influences the buyers' behaviors, and variation in the listing price generates a locus of possible outcomes. This discussion below is concerned with the interaction of the listing price and how it affects the marketing time and probability of selling a house.

One of the earliest studies on listing price and time on the housing market (Cubin, 1974) notes that, because of imperfect information in the housing market, buyers are uncertain about the true value of the house. This leads to some buyers using list price as an indication of house quality with the result that sellers who list a price below the average may experience a longer marketing time. In contrast, (Belkin, et al., 1976) proposed that a majority of buyers are attracted by price concessions. Belkin suggests houses that sold close to adjusted listing price typically had a short time on the market. (Miller, 1978) had suggested it was not possible to both maximize selling price and minimize selling time. A lower price relative to market value would generally result in a faster sale, but not necessarily at the highest price. We also know that different influencers on buyer and seller behavior affected pricing. This is because different parties involved in the sale of a property have different incentives. For example, brokers may be more focused on the ease and speed of the sale, while the owner may be more focused on maximizing the selling price (Belkin, et al., 1976; Miller, 1978). However, the primary challenge for these empirical papers is to determine whether the listing price is higher or lower than the true market value. In the 1970s, this was very difficult to accomplish.

In recent decades, the subject of marketing time and listing price relationship attracted more researchers; however, compared to the voluminous empirical literature related to the hedonic pricing model (HPM), literature regarding the time on the market is somewhat more limited (Sirmans, et al., 2010). (Miller \& Sklarz, 1987) confirmed that a greater degree of overpricing (listing price relative to value) results in longer marketing time and lower selling price. (Kang \& Gardner, 1989) also found overpricing to be a significant factor in lengthening the time on the market across all periods (low, medium, and high-interest rates) in U.S. housing market, whereas (Ferreira \& Sirmans, 1989) showed no impact of overpricing on the time on the market during periods of high-interest rates. The more recent published studies have validated the importance of the choice of listing price and the related degree of overpricing, showing that above-market pricing leads to a longer TOM (Yang \& Yavas, 1995; Jud, et al., 1996; Ong \& Koh, 2000; Knight, 2002; Anglin, et al., 2003; Johnson, et al., 2008; De Wit \& An Der Klaauw, 2013; Cirman, et al., 2015). However, other studies provide evidence that the impact of the listing price on TOM may change with housing market conditions. (Bjorklund, et al., 2006) based on over 12,000 observations in the county of Stockholm found that setting a listing price higher than the expected price will lead to a higher transaction price for up to 150 days of time on the market but, after that, the transaction price will decrease. (Bjorklund, et al., 2006, p. 423) explain that one reason could be that they are analyzing transactions in a booming housing market and, if the property is on the market a long time, it is an indication of a "lemon". Another reason could be that the relationship between price and TOM is not linear. Several studies (Yang \& Yavas, 1995; Arnold, 1999; Anglin, 2003; Haurin, et al., 2010) argue that the listing price has two roles in the housing market. One is that the listing price signals a property's quality. The other is that the listing price also signals a price, which is acceptable to the seller (Haurin, et al., 2013). (Hui, et al., 2012) found that the effect of overpricing on the probability of selling a house changed from a negative effect in 2003, 2004 when Hong Kong's economy had just begun to recover from the effects of the SARS epidemic, to positive effect in 2005, 2006, when Hong Kong's economy had gradually recovered.

Besides listing price, housing features are also important determinants of housing liquidity. According to (Miller, 1978), the marketing time of a house is a function of its relative characteristics compared to other houses on the market. In other words, the more unusual the home features, the more time required for a property to sell (Haurin, et al., 1988; Glower, et al., 1998; Krainer, 1999; Bourassa, et al., 2009; Haurin, et al., 2010, 2013).

Other elements influencing a house's marketing time refer to the seller's motivation, the estate agent, and market conditions. (Glower, et al., 1998) show that home sellers motivated to sell quickly 
will have a lower reservation price, set a lower listing price, receive a lower offer price, and accept earlier. The seller's motivation is defined by the gap between the actual listing price and the expected listing price estimated by the hedonic model (Anglin, et al., 2003). The higher the motivation of the seller, proxied by a lower gap, the higher the probability of sale (Johnson, et al., 2008). Early studies demonstrate that the size of a brokerage firm has a negative relationship with the time on the market of a house. Brokerage firms with higher numbers of agents sell houses faster than smaller firms (Sirmans, et al., 1991). However, recent studies could not confirm this relationship and found no evidence that the size of a brokerage firm affects the time on the housing market (Jud, et al., 1996; Elder, et al., 2000; Hardin, et al., 2009). The effectiveness of the Multiple Listing Service (MLS) should eliminate the advantage of the internal information large brokerage firms possess, so the role of estate agents is limited (Jud, et al., 1996).

\section{Theoretical framework}

Since (Kluger \& Miller, 1990) introduced the semi-parametric Cox Proportional Hazard model based on (Cox, 1972), several studies have used the Cox Proportional Hazard models to identify the factors that could influence the liquidity of a house, measured by the probability of a sale (Kluger \& Miller, 1990; Glower, et al., 1998; Mcgreal, et al., 2009; Hui, et.al., 2012; Haurin, et al., 2013; Cirman, et.al., 2015). This method allows a particularly flexible application, without any a priori assumptions regarding the distribution of the baseline hazard, in contrast to the widely used Weibull model (Cajias \& Freudenreich, 2018).

Prior to deriving the Cox Probability Hazard model, some statistical elements in the estimation of Cox survival regression need to be defined. The time period $\mathrm{T}$ is a continuous positive response variable without zeros representing the marketing time of a house with a cumulative distribution function $\mathrm{F}(\mathrm{t})=\operatorname{Pr}(\mathrm{T} \leq \mathrm{t})$ and probability density function of the marketing time $f(t)=\partial F(t) / \partial t$, in which $t$ is the time of the sale event. Two main measures are important for understanding and estimating survival models: the survival function (S) and the hazard rate function (h). Formally, the survival function $S(t)$ is the probability of a marketing house still being unsold at time $t$, defined as: $S(t)=\operatorname{Pr}(T>t)=1-F(t)$.

Since the probability of the house being sold at any point after $t$ and before $t+\Delta t$ is:

$$
\frac{\operatorname{Pr}(T \leq t+\Delta t \mid T>t)}{\operatorname{Pr}(T>t)}
$$

Therefore, the probability of a house being sold immediately at time $t$, also known as the hazard rate function, is defined as:

$$
h(t)=\lim _{\Delta t \rightarrow 0} \frac{\operatorname{Pr}(T \leq t+\Delta t \mid T>t)}{\operatorname{Pr}(T>t)}=\frac{f(t)}{S(t)}
$$

Equation (2) shows that the hazard ratio $h(t)$ gives the probability of an event per units of time, but the distribution function of the marketing time $\mathrm{F}(\mathrm{t})$ of houses (also known as the baseline of the survival model) has to be known. However, the absence of a priori information indicating which distribution should be used is the greatest limitation of the original survival model (SMITH 2010).

Cox (1972) has improved the flexibility of the hazard probability function of the survival model by adding the characteristics of the house into the hazard probability function. Cox argued that the probability of sale is high or low because of the impact of some specific characteristics of the house $(Z)$. Therefore, the hazard function of Cox model $h(t, Z)$ can be separated into two parts : (1) one is a baseline hazard function; (2) the other is the influence of the characteristics of the house on the probability of selling, called $\mathrm{g}(\mathrm{Z})$.

Thus, the Cox hazard function of a house can be rewritten as: $h(t, Z)=h_{0}(t) \cdot g(Z)$.

With the common form of the $g(Z)$ function is the Log-Linear form (Cirman, et al., 2015; Cajias \& Freudenreich, 2018): $g(Z)=\exp \left\{\beta_{1} Z^{1}+\beta_{2} Z^{2}+\cdots+\beta_{k} Z^{k}\right\}$

The interested house $\mathrm{i}$ has characteristics $Z_{i}=\left\{Z_{i}^{1}, Z_{i}^{2}, \ldots, Z_{i}^{k}\right\}$, the hazard probability of this house can be written as: $h\left(t, Z_{i}\right)=h_{0}(t) \cdot \exp \left\{\beta_{1} Z_{i}^{1}+\beta_{2} Z_{i}^{2}+\cdots+\beta_{k} Z_{i}^{k}\right\}$

Since the hazard ratio (HR) of the Cox model is defined as:

$$
H R=\frac{h\left(t, Z_{i}\right)}{h\left(t, Z_{0}\right)}=\frac{h_{0}(t) \cdot \exp \left\{\beta_{1} Z_{i}^{1}+\beta_{2} Z_{i}^{2}+\cdots+\beta_{k} Z_{i}^{k}\right\}}{h_{0}(t) \cdot \exp \left\{\beta_{1} Z_{0}^{1}+\beta_{2} Z_{0}^{2}+\cdots+\beta_{k} Z_{0}^{k}\right\}}
$$




$$
\begin{array}{r}
\text { Or } H R=\exp \left\{\beta_{1}\left(Z_{i}^{1}-Z_{0}^{1}\right)+\beta_{2}\left(Z_{i}^{2}-Z_{0}^{2}\right)+\cdots+\beta_{k}\left(Z_{i}^{k}-Z_{0}^{k}\right)\right\} \\
\text { Or } \operatorname{LnHR}=\operatorname{Ln}\left(\frac{h\left(t, Z_{i}\right.}{h\left(t, Z_{0}\right.}\right)=\beta_{1}\left(Z_{i}^{1}-Z_{0}^{1}\right)+\beta_{2}\left(Z_{i}^{2}-Z_{0}^{2}\right)+\cdots+\beta_{k}\left(Z_{i}^{k}-Z_{0}^{k}\right)
\end{array}
$$

Equation (5) shows that the coefficients of the Cox Probability Hazard model represent how the $Z_{i}$ characteristics of an interesting house impact this house's probability of sale compared with a typical house with $Z_{0}$ characteristics. Therefore, if the hazard ratio (the natural exponential function of coefficient) of the $Z_{1}$ characteristic $\left(H_{1}\right)$ is greater than one, the $Z_{1}$ feature increases the sale probability of the house at any point during the marketing time.

The importance in the Cox model is the fact that some observations in the research's database must not change their event status during the research time, referred to as censored observations. Therefore, in this study, censored observations are identified as the houses which still remain available on the market after the research period, i.e. no change in their status. The censored observations in our dataset excluded the houses that were traded but the landlord did not change the status in the multiple listing service database (Cajias \& Freudenreich, 2018), because we interviewed the brokers and the buyers directly.

\section{Research Methodology and Data source}

\subsection{Research Methodology}

The aim of this paper is to measure the dynamic effects of the listing price strategies and housing features on the probability of selling a house over various listing periods. Hence, the precise meaning of the listing price strategy has to be carefully defined Many authors argue that the direct use of the gap between the actual listing price and the actual selling price of the house to represent the seller's listing price strategy is potentially problematic because of the simultaneity of the two quantities (Yang \& Yavas, 1995; Hui, et al., 2012). Some empirical studies are susceptible to this problem, although some authors like (e.g Cubbin, 1974) are aware of this fact. To resolve this simultaneity problem, it is now popular to adopt a two-stage approach (Hui, et al., 2012). Therefore, this study will apply a twostage approach introduced by (Kluger \& Miller, 1990).

The first stage is to use hedonic regression to obtain the expected value of the sale price for a property described by house's characteristics, such as the age and size of a property, location conditions consisting of location dummy variables and the travel time to some utilities, as well as some dummy variables of neighborhood conditions (Kluger \& Miller, 1990; Glower, et al., 1998; Mcgreal, et al., 2009; Hui, et.al., 2012; Haurin, et al., 2013; Cirman, et. al., 2015).

$$
\operatorname{Ln}\left(P_{j}^{S}\right)=\alpha S_{j}+\beta L_{j}+\theta N_{j}+\varepsilon_{j}
$$

Where $P_{j}^{S}$ is the actual selling price of the house $\mathrm{j}$; $\mathrm{S}_{\mathrm{j}}$ is the vector of the structural characteristics of the house $\mathrm{j}$; $\mathrm{L}_{\mathrm{j}}$ is the vector of characteristics of location and accessibility of the house $\mathrm{j}$; and $\mathrm{N}_{\mathrm{j}}$ is a set of characteristics that belong to the area around the house $j$.

The expected value of the selling price for a property $E\left[\ln \left(\mathrm{P}_{\mathrm{j}}^{S}\right)\right]$ is then obtained as the predicted value of the selling price

$$
E\left[\operatorname{Ln}\left(P^{S}\right) \mid S_{j}, L_{j}, N_{j}\right]=\alpha S_{j}+\beta L_{j}+\theta N_{j}+\varepsilon_{j}
$$

To avoid the potential problem of heteroscedasticity, the hedonic models are estimated by applying a robust variance estimator.

Then, the expected sale price is used to estimate the degree of the price difference, DOP, the percentage of deviation from the actual listing price of this house. The DOP is calculated as:

$$
D O P=\operatorname{Ln}\left[\frac{P_{j}^{L}}{E\left(P_{j}^{S}\right)}\right]=\operatorname{Ln}\left(P^{l}\right)-E\left[\operatorname{Ln}\left(P^{S}\right) \mid S_{j}, L_{j}, N_{j}\right]
$$

The DOP ratio indicates a seller's listing price strategy, with DOP> 1 implying that the seller is applying an overpriced listing strategy, and DOP $<1$ pointing to an underpriced listing strategy.

There are two different points of view to measure DOP. Accordingly, one is that DOP is the difference between the actual listing price and expected listing price (Anglin, et al., 2003; Johnson, et al., 2008). Another is the difference between the actual listing price and expected selling price (Kluger \& Miller, 1990; Hui, et. al., 2012). In the Vietnam housing market, real estate brokers or housing 
appraisers often provide sellers with information about the transacted price of similar houses in the local housing market instead of the listing prices. This means that the sellers usually decide on the listing price when they know about the average transaction price (or expected selling price) of the house in the market. This study therefore employs DOP, which is defined as the difference between the actual listing price and expected selling price because of a better measurement of the seller's listing strategy (Hui, et al., 2012).

In the second stage, the seller's listing price strategy (DOP) obtained from the first stage is used as the explanatory variable (among other house's feature variables) in Cox Probability Hazard models. These Cox models also include the house's feature variables, location and accessibility variables, and neighborhood condition variables to measure the effect of these variables on the probability of selling the house.

The hazard ratio of these variables estimated from the Cox model is used to measure their impacts on the probability of selling houses. As discussed in the theoretical framework, if the hazard ratio of a variable is larger than one, then an increase in the value of the variable would result in a higher probability of sale, which implies a shorter time on the market. Otherwise, an increase in the value of the variable would tend to make the probability of sale lower or time on the market longer.

To examine the dynamic effect of the seller's listing price strategy and other house's features on the probability of sale, this study will estimate Cox models with several marketing periods, such as 30day, 90-day, 180-day, and 270-day. For example, the houses whose marketing time is between 30 days and 90 days will be considered as censored observations in the 30-day Cox model but not in the 90day Cox model. The changing of the hazard ratio of a variable between 30-day, 90-day, 180-day and 270-day Cox models will show the dynamic effect of this variable on the house's probability of sale over marketing time.

\subsection{Data source}

The housing market in Ho Chi Minh City (HCMC - the largest city of Vietnam) started to develop in the early 1990s with the country's transition to a market economy, and has significantly developed in the early 2000s due to the explosion of migration from rural areas. The housing market in HCMC is divided into a primary and secondary segment. In which, the supply-side of the primary housing market consists mostly of large real estate development companies, building similar new houses in an authorized area with a non-negotiable price which had already been officially announced by the suppliers. In contrast, the secondary housing market consists mostly of individual buyers and sellers with relative equality in their own bargaining power for each transaction in the real estate market. They often employ the services of local real estate brokers to support their search or selling transaction process because of the knowledge brokers have with respect to the developing housing market and the complexity of real estate laws, the differences in administrative procedures between localities, and the underdevelopment of information systems in Vietnam.

In the HCMC's secondary housing market, most real estate brokers are individual brokers or smallscale brokerage firms, operating mainly within a submarket or specialized geographic area. Most brokers have a relationship with local real estate administrative managers, providing flexible brokerage services without any fixed procedures. The brokers will provide information on the transaction prices of similar houses in the neighborhood to sellers and offer several possible listing prices. Then, based on the seller's listing price, the broker searches for potential buyers through their own information networks, acts as an intermediary in the negotiation process between buyers and sellers, and receives from $1-5$ percent of the transaction price as a commission. This implies that, because of the absence of a sharing information system like Multiple Listing Service (MLS) in HCMC's housing market, the information needed for this study must be collected from the brokers operating in HCMC's secondary housing market. To control for the effect that different real estate brokerage firms' size might have on the time on the market, we try to collect data from similarly sized brokerage firms, with around $5-7$ agents per firm.

The data for this study are based on 448 single-family house transactions from the secondary housing market in 19 urban areas of Ho Chi Minh City (excluding 5 suburban areas) from September 2017 through May 2018. The single-family house characteristics include four sets of variables, often used in hedonic price models (Sirmans, et al., 2006). The first set comprises information on listing prices, selling price and the time on the market of transacted houses. The selling price and time on the market are used as dependent variables in the expected market price model and the Cox model. 
Listing price is used to calculate the difference of price (DOP), which is considered as a listing price strategy of the seller. The second set of variables are independent physical attributes describing the property characteristics of the houses, such as the age and size of the house as well as the shape of the land, road frontage or distance from the road, and width of the road in front of the house. These two sets of data were collected from brokers. With the third set of variables, we control for accessibility of the house such as distance and time to commute to the central business district (CBD), the nearest markets, and nearest schools. Area variables (districts), where the property is located, are also included in the model as district control dummy variables. The fourth set of variables are specific neighborhood status indices, such as safety ratings, waste collection ratings, and flood risks. The third and fourth sets of variables are collected by interviewing buyers.

The basic descriptive statistics of these variables are presented in Table 1. The mean size of a single-family house in the sample was just above 70 square meters ( 4.5 meters wide and 16 meters long), and around 2.5 floors, and it sold for just around VND110 millions per square meter (around USD 4,800 per square meter); the numbers are close to the official statistics, making the sample representative.

Table 1

Housing Survey Sample in Ho Chi Minh City

\begin{tabular}{|c|c|c|c|c|c|c|}
\hline $\begin{array}{l}\text { Variable } \\
\text { name }\end{array}$ & Unit & Description & Mean & Std. Dev. & Min & $\operatorname{Max}$ \\
\hline Price & Million VND & Price & 7932.45 & 5777.35 & 900 & 26600 \\
\hline Tom & Days & Time on market & 114.38 & 130.14 & 1 & 884 \\
\hline Age & Years & Age of house & 8.93 & 7.18 & 1 & 30 \\
\hline Lot_area & square meter & Lot size & 71.21 & 36.64 & 25 & 320 \\
\hline Floor_area & square meter & Square footage & 186.75 & 111.70 & 44 & 600 \\
\hline Shape & $\begin{array}{l}0 \text { square/grew bigger } \\
1 \text { otherwise }\end{array}$ & shape of the land & 0.82 & 0.39 & 0 & 1 \\
\hline Wide & meter & Width of house & 4.49 & 1.44 & 3 & 12 \\
\hline Long & meter & Long of house & 15.66 & 4.93 & 6.8 & 32 \\
\hline Nbedr & No. of rooms & Number of bedrooms & 3.83 & 1.88 & 1 & 14 \\
\hline Nbathr & No. of rooms & Number of bathrooms & 3.50 & 2.00 & 1 & 15 \\
\hline Sun & $\begin{array}{l}0 \text { sunshine } \\
1 \text { otherwise }\end{array}$ & $\begin{array}{l}\text { house facing afternoon } \\
\text { sunshine (hot) }\end{array}$ & 0.36 & 0.48 & 0 & 1 \\
\hline Face & $\begin{array}{l}0 \text { alley } \\
1 \text { frontage }\end{array}$ & Road frontage & 0.23 & 0.42 & 0 & 1 \\
\hline Dstreet & meter & Distance from road frontage & 89.18 & 163.39 & 0 & 1000 \\
\hline Widestreet & meter & $\begin{array}{l}\text { width of the road in front of } \\
\text { the house }\end{array}$ & 8.69 & 6.30 & 1 & 30 \\
\hline Dcbd & Kilometer & Distance to CBD & 8.15 & 3.92 & 0.6 & 16.4 \\
\hline Dmarket & Kilometer & Distance to nearest market & 0.89 & 1.19 & 0 & 12 \\
\hline Dsch & Kilometer & Distance to nearest school & 0.77 & 0.66 & 0 & 5 \\
\hline Tcbd & Minutes & Time to CBD & 22.98 & 10.22 & 1 & 60 \\
\hline Tworkpla & Minutes & Time to working place & 14.38 & 8.00 & 1 & 40 \\
\hline Tmarket & Minutes & Time to nearest market & 6.41 & 5.92 & 1 & 55 \\
\hline Tsch & Minutes & Time to nearest school & 6.85 & 3.61 & 1 & 22.5 \\
\hline Safe & $\begin{array}{l}1 \text { is worst } \\
7 \text { is best }\end{array}$ & $\begin{array}{l}\text { Status of safety in the } \\
\text { neighborhood }\end{array}$ & 5.83 & 1.21 & 1 & 7 \\
\hline
\end{tabular}




\section{$\$$ sciendo}

\begin{tabular}{lllllll}
\hline Smelly & $\begin{array}{l}\text { 1 is worst } \\
7 \text { is best }\end{array}$ & $\begin{array}{l}\text { Status of smell in } \\
\text { neighborhood }\end{array}$ & 4.68 & 1.95 & 1 & 7 \\
\hline Noisy & $\begin{array}{l}1 \text { is worst } \\
7 \text { is best }\end{array}$ & $\begin{array}{l}\text { Status of quiet condition in } \\
\text { the neighborhood }\end{array}$ & 5.06 & 1.81 & 1 & 7 \\
\hline Waste & $\begin{array}{l}\text { 0 no garbage collection } \\
\text { system. } \\
1 \text { otherwise }\end{array}$ & $\begin{array}{l}\text { Status of garbage collection } \\
\text { in the neighborhood }\end{array}$ & 0.61 & 0.37 & 0 & 1 \\
\hline Flooding & $\begin{array}{l}\text { 0 no flooding } \\
1 \text { flooding }\end{array}$ & $\begin{array}{l}\text { Status of flooding in the } \\
\text { neighborhood }\end{array}$ & 0.90 & 0.29 & 0 & 1 \\
\hline
\end{tabular}

Source: calculated by authors.

\section{Research results}

\subsection{Estimate the expected value of the selling price of a house}

In the first stage of the two-stage method, we estimate the expected value of the selling price of a house by the hedonic model, defined by Equation (6). The results of the selling price models, presented in Table 2, established by house physical attributes, location, accessibility, and environmental characteristics of the neighborhood area are statistically significant determinants.

Table 2

Price regression model basing on housing characteristics

\begin{tabular}{|c|c|c|c|c|c|c|c|c|c|}
\hline \multirow[b]{2}{*}{ Variables } & \multicolumn{3}{|c|}{ Model 1} & \multicolumn{3}{|c|}{ Model 2} & \multicolumn{3}{|c|}{ Model 3} \\
\hline & Coef. & $\begin{array}{l}\text { Robust } \\
\text { Std. Err. }\end{array}$ & VIF & Coef. & $\begin{array}{l}\text { Robust Std. } \\
\text { Err. }\end{array}$ & VIF & Coef. & $\begin{array}{c}\text { Robust } \\
\text { Std. Err. }\end{array}$ & VIF \\
\hline Lnage & -0.032 & 0.020 & 3.4 & $-0.042 * *$ & 0.020 & 3.5 & $-0.037 * *$ & 0.018 & 3.6 \\
\hline LnFloor_area & $0.182^{* * *}$ & 0.051 & 4 & $0.163 * * *$ & 0.039 & 2.3 & $0.152 * * *$ & 0.037 & 2.3 \\
\hline Floor_areasqu & $1.26 \mathrm{E}-07$ & $3.7 \mathrm{E}-07$ & 3.7 & & & & & & \\
\hline LnLot_area & $0.604 * * *$ & 0.074 & 5.1 & $0.625 * * *$ & 0.072 & 5.1 & $0.530 * * *$ & 0.056 & 2.8 \\
\hline Lot_areasqu & $-3.5 \mathrm{E}-06^{*}$ & $2.1 \mathrm{E}-06$ & 2.9 & $-3.9 \mathrm{E}-06^{*}$ & $2.2 \mathrm{E}-06$ & 2.9 & & & \\
\hline Face & $0.106^{*}$ & 0.063 & 2.8 & 0.081 & 0.058 & 3.3 & & & \\
\hline Shape & $-0.089 * *$ & 0.035 & 1.2 & $-0.084 * *$ & 0.033 & 1.2 & $-0.089^{*}$ & 0.035 & 1.2 \\
\hline Widestreet & $0.015^{* * *}$ & 0.004 & 2.6 & $0.015^{* * *}$ & 0.004 & 2.8 & $0.018^{* * *}$ & 0.002 & 1.5 \\
\hline Acar & & & & $0.182 * *$ & 0.092 & 1.3 & $0.147^{*}$ & 0.083 & 1.3 \\
\hline Dstreet & & & & $-1.5 \mathrm{E}-04^{*}$ & $8.5 \mathrm{E}-05$ & 1.8 & $-1.5 \mathrm{E}-04^{*}$ & $7.9 \mathrm{E}-05$ & 1.5 \\
\hline LnTworkpla & & & & $-0.051^{* *}$ & 0.021 & 1.2 & $-0.047 * *$ & 0.021 & 1.3 \\
\hline LnTcbd & & & & $-0.069 * * *$ & 0.025 & 1.8 & $-0.067 * *$ & 0.030 & 1.9 \\
\hline Sun & & & & $0.0672 * * *$ & 0.024 & 1.2 & $0.054 * *$ & 0.024 & 1.3 \\
\hline Safe & & & & & & & 0.014 & 0.014 & 1.7 \\
\hline Waste & & & & & & & 0.059 & 0.045 & 1.2 \\
\hline Smelly & & & & & & & $0.036^{* * *}$ & 0.009 & 2 \\
\hline Noisy & & & & & & & $-0.030^{* * *}$ & 0.011 & 1.9 \\
\hline Flooding & & & & & & & $-0.090 * *$ & 0.043 & 1.3 \\
\hline cons & $4.824 * * *$ & 0.312 & & $5.078 * * *$ & 0.293 & & $5.468^{* * *}$ & 0.265 & \\
\hline $\begin{array}{l}\text { District Control } \\
\text { Dummy }\end{array}$ & & Yes & & & Yes & & & Yes & \\
\hline R-squared & & 0.8706 & & & 0.8795 & & & 0.888 & \\
\hline $\operatorname{Prob}(\mathrm{F})$ & & 0 & & & 0 & & & 0 & \\
\hline Root MSE & & .24958 & & & 0.24195 & & & 23412 & \\
\hline Dep. Var. & & Lnprice & & & Lnprice & & & nprice & \\
\hline N. of obs & & 448 & & & 448 & & & 448 & \\
\hline
\end{tabular}


Note: $*, * *, * * *$ significance at $10 \%, 5 \%$ and $1 \%$.

Source: calculated by authors.

As the age of a house increases, its selling price decreases; an old house requires a higher level of annual maintenance and repair cost, and often has outdated electrical and mechanical systems (VISSER et al. 2008; UJU, IYANDA 2012). The size of the house has the opposite effect; an additional square meter of house, either square footage or lot size, increases the selling price. However, the nonlinear effect of size is eliminated because of the multicollinearity problem.

In addition to size, homes with square land plots, more convenient access (the width of an alley, depth of an alley) also have an impact on the selling price. Especially, because a large number of single-family houses in Ho Chi Minh City are located in small alleys (with access for only motorbikes and bikes), the presence of car-access is very valuable for residents and has a great positive effect on the selling price. The travel time to the workplace and to central business areas also has an effect on the selling price. Other similar elements, such as the travel time to schools or markets, do not affect the selling price because HCMC's citizens often take their children to school when they transit to work, then pick up the children from school and buy food on their way home.

The main purpose of selling price models is to estimate the expected selling price of a house, defined by house structural characteristics, location and accessibility features, and environmental characteristics of the neighborhood area. Therefore, the best explanatory model (Model 3) was chosen to estimate the expected selling price, according to the definition of equation (7).

The expected selling price was used to create a variable measuring the seller's listing price strategies, DOP, defined as Equation (8). This variable was then used as an explanatory variable in Cox models.

\subsection{Effects of housing characteristics on the probability of selling a house}

In the second stage, the listing price strategy variable (DOP) and other characteristic variables of the house are included in the 30-day, 90-day, 180-day, and 270-day Cox Probability Hazard models to measure the dynamic effect on probability of selling a house, whereas a hazard ratio above one implies that a one-unit increase in the explanatory variable is associated with an increase in the hazard and therefore increases the liquidity of a house (shortens the survival time). The results of Cox models are presented in Table 3.

Table 3

The 30-day, 90-day, 180-day, and 270-day Cox Probability Hazard models

\begin{tabular}{lcccccccc}
\hline & 30-day Cox model & 90-day Cox model & 180-day Cox model & \multicolumn{2}{c}{ 270-day Cox model } \\
\hline & $\begin{array}{l}\text { Haz. } \\
\text { Ratio }\end{array}$ & $\begin{array}{c}\text { Robust } \\
\text { Std. Err. }\end{array}$ & $\begin{array}{c}\text { Haz. } \\
\text { Ratio }\end{array}$ & $\begin{array}{c}\text { Robust } \\
\text { Std. Err. }\end{array}$ & $\begin{array}{c}\text { Haz. } \\
\text { Ratio }\end{array}$ & $\begin{array}{c}\text { Robust } \\
\text { Std. Err. }\end{array}$ & $\begin{array}{c}\text { Haz. } \\
\text { Ratio }\end{array}$ & $\begin{array}{c}\text { Robust Std. } \\
\text { Err. }\end{array}$ \\
\hline DOP & $2.231^{*}$ & 1.058 & $1.681^{*}$ & 0.513 & $1.567^{*}$ & 0.430 & 1.364 & 0.346 \\
\hline Age & 1.011 & 0.018 & 1.011 & 0.011 & $1.025^{* * *}$ & 0.001 & $1.026^{* * *}$ & 0.001 \\
\hline LnFloor_area & 1.173 & 0.292 & 1.056 & 0.167 & 1.201 & 0.173 & 1.173 & 0.160 \\
\hline LnLot_area & $0.336^{* * *}$ & 0.126 & $0.628^{* *}$ & 0.146 & $0.596^{* *}$ & 0.125 & $0.590^{* *}$ & 0.124 \\
\hline Widestreet & 0.983 & 0.021 & 1.002 & 0.012 & 0.991 & 0.011 & 0.995 & 0.010 \\
\hline Acar & $3.327^{*}$ & 2.363 & 0.858 & 0.248 & 0.873 & 0.225 & 0.923 & 0.251 \\
\hline Dstreet & 1.001 & 0.001 & 1.001 & 0.000 & 1.000 & 0.000 & 1.000 & 0.000 \\
\hline LnTcbd & 0.975 & 0.241 & 1.170 & 0.190 & 1.235 & 0.173 & 1.108 & 0.136 \\
\hline LnTworkpla & 0.924 & 0.179 & 0.999 & 0.117 & 1.170 & 0.116 & 1.168 & 0.114 \\
\hline Sun & 1.183 & 0.250 & 1.166 & 0.158 & 1.105 & 0.133 & 1.133 & 0.133 \\
\hline Safe & $1.156^{*}$ & 0.091 & $1.155^{*}$ & 0.064 & $1.147^{* * *}$ & 0.060 & $1.136^{* *}$ & 0.060 \\
\hline Waste & $1.665^{* * *}$ & 0.279 & $1.758^{* * *}$ & 0.221 & $1.695^{* * *}$ & 0.232 & $1.612^{* * *}$ & 0.233 \\
\hline Smelly & $1.234^{* * *}$ & 0.098 & $1.155^{* * *}$ & 0.052 & $1.082^{* *}$ & 0.040 & $1.081^{* *}$ & 0.040 \\
\hline Noisy & $0.829^{* * *}$ & 0.050 & $0.841^{* * *}$ & 0.033 & $0.877^{* * *}$ & 0.032 & $0.893^{* * *}$ & 0.033 \\
\hline
\end{tabular}




\begin{tabular}{|c|c|c|c|c|c|c|c|c|}
\hline Flooding & 1.116 & 0.428 & 0.965 & 0.217 & 1.072 & 0.218 & 1.055 & 0.220 \\
\hline & \multicolumn{2}{|c|}{ No. of subjects $=448$} & \multicolumn{2}{|c|}{ No. of subjects $=448$} & \multicolumn{2}{|c|}{ No. of subjects $=448$} & \multicolumn{2}{|c|}{ No. of subjects $=448$} \\
\hline & \multicolumn{2}{|c|}{ No. of failures $=108$} & \multicolumn{2}{|c|}{ No. of failures $=260$} & \multicolumn{2}{|c|}{ No. of failures $=366$} & \multicolumn{2}{|c|}{ No. of failures $=380$} \\
\hline & \multicolumn{2}{|c|}{ Wald chi2(15) $=58.32$} & \multicolumn{2}{|c|}{ Wald chi2(15) $=90.67$} & \multicolumn{2}{|c|}{ Wald chi2(15) $=62.03$} & \multicolumn{2}{|c|}{ Wald chi2 $(15)=55.25$} \\
\hline & \multicolumn{2}{|c|}{ Prob $>$ chi $2=0$} & \multicolumn{2}{|c|}{ Prob $>$ chi $2=0$} & \multicolumn{2}{|c|}{ Prob $>$ chi $2=0$} & \multicolumn{2}{|c|}{ Prob $>$ chi $2=0$} \\
\hline
\end{tabular}

Source: calculated by authors.

Since Cox hazard models estimate event (sale) probabilities per unit of marketing time, the Wald_Chi_square (a substitute of R_square indicate) measures the concordance between estimated survival time and the observed survival time; values between $50 \%-90 \%$ are common in survival studies (Cajias \& Freudenreich, 2018).

Comparing the hazard ratio of the DOP variable between the 30-day, 90-day, 180-day, and 270-day Cox Probability Hazard models, we find that, with the exception of the 270-day Cox model, the overpriced listing strategy has a positive and significant effect on the probability of a sale. A one percent increase in DOP results, on average, ceteris paribus, in a 1.23 percent increase in the probability that a property is sold at any point during the first 30 days of the marketing time. After the $30^{\text {th }}$ marketing day, this effect seems to diminish and disappear totally after 6 months of marketing time.

Why an overpriced listing strategy is able to produce a higher probability of sale could be the result of market conditions. The HCMC's housing market has experienced a period of decline from 2009 through 2015, with a relatively low property price index and a low absorption rate (around 10\% $20 \%$ ) (Fig. 1 below). The HCMC's housing market then started to recover in 2016, with a continuous increase in the house price index quarter-on-quarter (QoQ Index). The HCMC's housing market experienced a rapid increase of absorption rate starting in Q1.2017, reaching around 50\% - 59\% near the end of the research period. The result has been an insufficient stock of homes for sale on the market relative to demand and a severe shortage of HCMC's housing in the last few periods of this study.

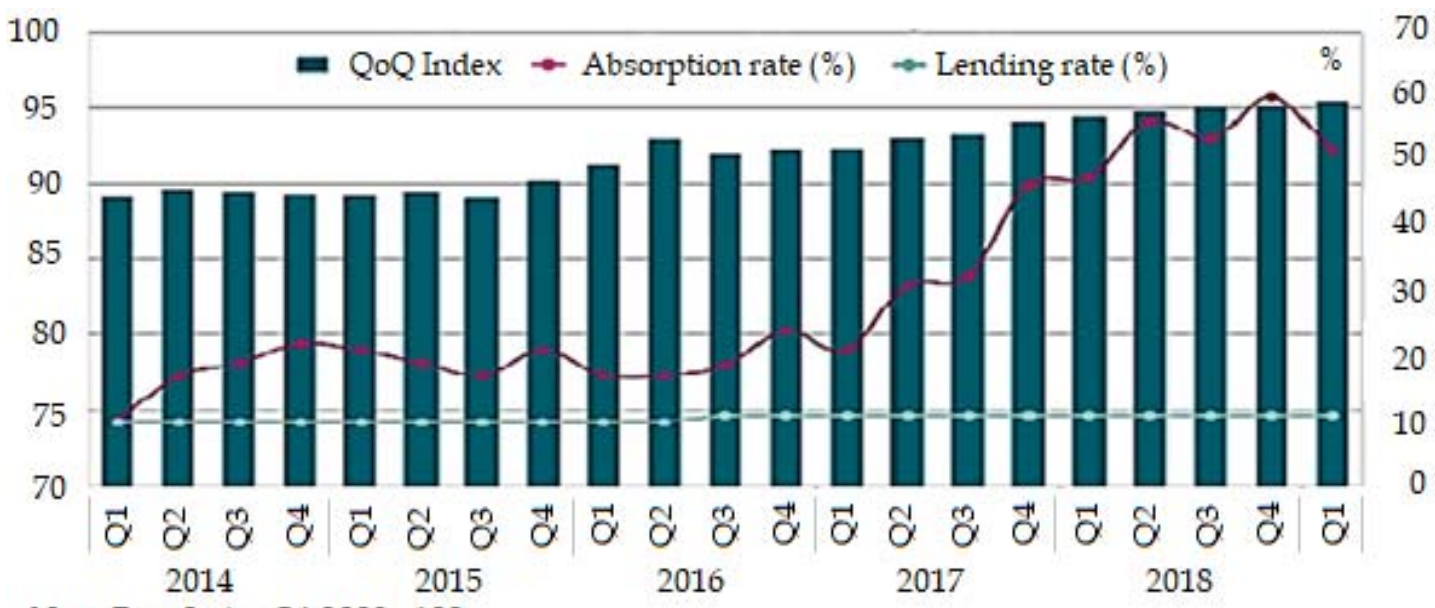

Note: Base Index Q1 2009 - 100

Fig. 1. HCMC Property Price Quarter on Quarter (QoQ) Index. Source: Savills Research and Consultancy.

During this market of severe shortages of housing available for sale, a rational seller will list at a higher price and buyers will feel an urgency to purchase the house as soon as possible (Hui, et al., 2012) because the cost of waiting for the buyer is extremely high during a period of high absorption for all new listings. In contrast, houses with unclear price expectations are often listed close to the market price and often have a longer marketing time because they are less attractive to buyers, who may use price as a proxy for quality. In summary, the effects of overpricing on the liquidity of houses are determined by the opportunity cost of waiting for buyers (Hui, et al., 2012) reflected by the market's absorption rate and the buyers' expectations and estimation of market value. With the prolongation of marketing time (the house is still unsold), the expectations of home buyers are 
reduced (Taylor, 1999), leading to a diminishing effect of an overpricing strategy on the probability of a sale. When the marketing time exceeds 180 days (six months), this effect of DOP disappears.

Specific features may also affect the liquidity of a home listed for sale. The small size of the land lot is found to increase the probability of selling the house. This means that HCMC's home buyers prefer a more affordable small lot size. This is understandable because the average GDP per capita of Ho Chi Minh in 2018 is around 6,300 USD (HCM's People's Committee report), too low in relation to the price of single-family houses (sample mean is 7.9 billion VND or 340,000 USD). This effect of lot size weakens after the first 30 days of sale, showing a prolongation of the marketing time of the preferred house (small lot size) and a dramatic reduction in the expectations of home buyers, leading to the diminishing effect of lot size.

A house with the car accessibility is 2.4 times more likely to be sold than a similar house without car- accessibility at any point during the first 30 days of marketing time; after this time, the feature no longer impacts the probability of a sale. The reason behind this phenomenon may be the differences in behaviors between two groups of buyers. The buyers with abundant financial capacity, attracted by the car-accessibility, often have a short search process because of high opportunity cost. Therefore, the houses purchased by these buyers will have a short marketing time (shorter than 30 days). Conversely, financially limited buyers, who are not attracted by car-accessibility, often have a longer search process, with longer negotiation and buying decision time. Therefore, the marketing time of houses purchased by such buyers is typically longer than 30 days.

\section{Conclusions}

This study examines the dynamic effects of listing price strategies and a variety of house features on the probability of a sale. The study deploys a two-stage method. In the first stage, the listing price strategy is measured by the difference between the actual listing price and the expected selling price, estimated through a hedonic pricing model. In the second stage, the listing price strategy (DOP) and other characteristic variables of the house are included in the 30-day, 90-day, 180-day, and 270-day Cox Probability Hazard models to measure the dynamic effects on the probability of selling a house over the marketing time.

This study found that, when the housing market is experiencing a high absorption rate, an overpriced listing strategy is an appropriate strategy during the first 30 days of marketing time because it helps sellers signaling an expectation of an even higher price in the near future and thus increases the probability of a sale. However, this effect seems to diminish after the first 30 days of marketing time and disappears after 6 months of the marketing time because the expectations of homebuyers are reduced with the prolongation of the time the house is on the market (Taylor, 1999). Besides listing price strategies, the features of lot size and car-accessibility are also found to have a strong effect on the probability of sale during the first 30 days of marketing time. Conversely, the specific neighborhood status has a stable effect on the probability of sale over the marketing periods.

These results imply that the first 30 days of marketing time are very important, and the liquidity of the house can be strongly influenced by the seller's strategies during this period. With the prolongation of the marketing time, attempts to improve house liquidity will be less effective.

\section{References}

Anglin, P. M., Rutherford, R. C., \& Springer T. M. (2003). The Trade-off Between Selling Price of Residential Properties and Time-on-the-Market: The Impact of Price Setting. Journal of Real Estate Finance and Economics, 26(1), 95-111.

Arnold, M. (1999) Search, Bargaining and Optimal Asking Prices. Real Estate Economics, 27(3), 453-481. https://doi.org/10.1111/1540-6229.00780

Belkin, J., Hempel, D. J., \& Mcleavey D. W. (1976) An Empirical Study of Time on Market Using Multidimensional Segmentation of Housing Markets. Real Estate Economics, 4(2), 57-75. https://doi.org/10.1111/1540-6229.00156

Benefield, J., Cain, C., \& Johnson, K. (2014) A review of literature utilizing simultaneous modeling techniques for property price and time-on-market. Real Estate Literature, 22(2), 149-175.

Bhuiyan, M., \& Hasan, M. A. (2016) Waiting to be Sold: Prediction of Time Dependent House Selling Probability. IEEE International Conference on Data Science and Advanced Analytics, 468-477. https://doi.org/10.1109/DSAA.2016.58 
Bjorklund, K., Dadzie, J. A., \& Wilhelmsson, M. (2006) Offer Price, Transaction Price and Time-onmarket. Property Management, 24(4), 415-426.

Bourassa, S., Haurin, D. R., Haurin, J. L., Hoesli, M., \& Sun J. (2009) House price changes and idiosyncratic risk: the impact of property characteristics. Real Estate Economics, 37(2), 259-278. https://doi.org/10.1111/j.1540-6229.2009.00242.x

Cajias, M., \& Freudenreich, F. (2018) Exploring the determinants of liquidity with big data-market heterogeneity in German markets. Property Investment $\mathcal{E}$ Finance, 36(1), 3-18. https://doi.org/10.1108/JPIF-01-2017-0006

Cirman, A., Pahor, M., \& Verbic, M. (2015) Determinants of Time on the Market in a Thin Real Estate $\begin{array}{lllll}\text { Market. Inzinerine Ekonomika-Engineering } & \text { Economics, }\end{array}$ https://doi.org/10.5755/j01.ee.26.1.3905

Cox, D. R. (1972) Regression models and life-tables. Journal of the Royal Statistical Society. Series B, 34(2), 187-220. https://doi.org/10.1111/j.2517-6161.1972.tb00899.x

Cubbin, J. (1974) Price, Quality and Selling Time in the Housing Market. Applied Economics, 6(3), 171187. https://doi.org/10.1080/00036847400000017

De Wit, E. R., \& van der Klaauw, B. (2013), Asymmetric information and list-price reductions in the housing market. Regional Science and Urban Economics, 43(3), 507-520. https://doi.org/10.1016/j.regsciurbeco.2013.03.001

Dubé, J., \& Legros D. (2016) A Spatiotemporal Solution for the Simultaneous Sale Price and Time-onthe-Market Problem. Real Estate Economics, American Real Estate and Urban Economics Association, 44(4), 846-877. https://doi.org/10.1111/1540-6229.12121

Elder, H. W., Zumpano, L. V., \& Baryla E. A. (2000) Buyer brokers: do they make a difference? Their influence on selling price and search duration. Real Estate Economics, 28(2), 337-62. https:// doi.org/10.1111/1540-6229.00804

Ferreira, E. I., \& Sirmans, G. S. (1989). Selling Price, Financing Premiums, and Days on the Market. The Journal of Real Estate Finance and Economics, 2(3), 209-222. https://doi.org/10.1007/BF00152349

Glower, M., Haurin, D. R., \& Hendershott, P.H. (1998) Selling Price and Selling Time: The Impact of Seller Motivation. Real Estate Economics, 26(4), 719-740.

Hardin Iii W.G., Johnson K.H., Wu Z., 2009, Brokerage Intermediation in the Commercial Property Market, Journal of Real Estate Research, 31(4), 397-420

Harding, J.P., Knight J.R., Sirmans C.F., 2003, Estimating Bargaining Effects in Hedonic Models: Evidence from the Housing Market, Real Estate Economics, 31(4), 601-622.

Haurin, D. R., Haurin, J. L., Nadauld, T., \& Sanders, A. (2010). List prices sale prices and marketing time An application to US housing markets. Real Estate Economics, 38(4), 659-685. https://doi.org/10.1111/j.1540-6229.2010.00279.x

Haurin, D. R. (1988). The Duration of Marketing Time of Residential Housing. American Real Estate and Urban Economics Association, 16(4), 396-410.

Haurin, D. R., Mcgreal, S., Adair, A., Brown, L., \&Webb J. R. (2013). List price and sales prices of residential properties during booms and busts. Journal of Housing Economics, 22 (1), 1-10.

Hui, E. C. M., Joe, T., Wong, Y., \& Wong K. T. (2012). Marketing Time and Pricing Strategies. Journal of Real Estate Research, 34(3), 375-398.

Johnson, K. H., Benefield, J. D., \& Wiley J.A. (2008). The Probability of Sale for Residential Real Estate. Journal of Housing Research, 16(2), 131-142.

Jud, G. D., Seaks, T. G., \& Winkler, D.T. (1996). Time on the Market: The Impact of Residential Brokerage. Journal of Real Estate Research, 12(3), 447-458.

Kang, H. B., \& Gardner, M. J. (1989). Selling Price and Marketing Time in the Residential Real Estate Market. Journal of Real Estate Research, (4), 21-36.

Kluger. B. D., \& Miller N. G. (1990). Measuring Real Estate Liquidity. Journal of Real Estate Economics, 18(2), 145-159.

Knight, J. R. (2002). Listing Price, Time on Market, and Ultimate Selling Price: Causes and Effects of Listing Price Changes. Real Estate Economics, 30(2), 213-237. https://doi.org/10.1111/15406229.00038

Krainer, J. (1999). Real estate liquidity. Journal of Economic Review, Federal Reserve Bank of San Francisco, 14-26. 
Levitt, S. D., \& Syverson, C. (2008). Market Distortions When Agents Are Better Informed: The Value of Information in Real Estate Transactions. The Review of Economics and Statistics, MIT Press, 90(4), 599-611,

Li, W. F. (2004). The Impact of Pricing on Time-on-market in High-rise Multiple-unit Residential Developments. Pacific Rim Property Research Journal, 10(3), 305-27. https://doi.org/10.1080/14445921.2004.11104165

Mcgreal, S., Adair, A., Brown, L., \& Webb, J.R. (2009). Pricing and Time on the Market for Residential Properties in a major U.K. City. Journal of Real Estate Research, 31(2), 209-233.

Miller, N. G. (1978). Time on the Market and Selling Price. Real Estate Economics, 6(2), 164-174. https://doi.org/10.1111/1540-6229.00174

Miller, N. G., Sklarz, \& M. A. (1987). Pricing Strategies and Residential Property Selling Prices. Journal of Real Estate Research, 2(1), 31-40.

Ong, S. E., \& Koh Y. C. (2000). Time On-market and Price Trade-offs in High-rise Housing Submarkets. Urban Studies, 37(11), 2057-2071. https://doi.org/10.1080/713707223

Savills Research And Consultancy available at https://pdf.savills.asia/asia-pacific-research/vietnamresearch/savills-property-price-index/sppi-vn-q1-2019-en.pdf - retrieved 12-12-2019.

Sirmans, C. F., Turnbull, G. K., \& Benjamin, J.D. (1991). The Markets for Housing and Real Estate Broker Services. Journal of Housing Economics, 1(3), 207-217. https://doi.org/10.1016/S10511377(05)80033-6

Sirmans, G. S., Macdonald, L., \& Macpherson, D. A. (2010). A Meta-Analysis of Selling Price and Time-on-the-Market. Journal of Housing Research, 19(2), 139-152.

Sirmans, G. S., Macdonald, L., Macpherson, D. A., \& Zietz, E. N. (2006). The Value of Housing Characteristics: A Meta Analysis. Real Estate Finance and Economics, 33(3), 215-240. https://doi.org/10.1007/s11146-006-9983-5

Smith, B. C. (2010). Spatial Heterogeneity in Listing Duration: The Influence of Relative Location to Marketability. Journal of Housing Research, 18(2), 151-171.

Taylor, C. (1999). Time-on-the-Market as the Sign of Quality. Review of Economic Studies, 66(3), 555-578. https://doi.org/10.1111/1467-937X.00098

Tracy, J., \& Schneider, H. (2001). Stocks in the Household Portfolio: A Look Back at the 1990s. Current Issues in Economics and Finance, Federal Reserve Bank of New York, 7(4), 1-6.

Turnbull, G. K., \& Dombrow, J. (2007) Individual Agents, Firms, and the Real Estate Brokerage Process. Journal of Real Estate Finance and Economics, 35(1), 57-76. https://doi.org/10.1007/s11146007-9025-y

Uju, I. V., \& Iyanda, S.T. (2012). Comparative Analysis of the Determinants of Residential Land Values. Chinese Business Review, 11(2), 187-192.

Visser, P., Van Dam, F., \& Hooimeijer, P. (2008). Residential Environmental and Spatial variation in house prices in the Netherlands. Journal of Social \& Economic Geography, 99(3), 348-360.

Wood, H., \& Wood, N. L. (1985). Financial Markets. Harcourt Brace Jovanovich.

Yang, S. X., \& Yavas, A. (1995). Bigger Is Not Better: Brokerage and Time on the Market. Journal of Real Estate Research, 10(1), 23-33.

Zuehlke, T. W. (1987). Duration Dependence in the Housing Market. Review of Economics and Statistics, 69(4), 701-704. https://doi.org/10.2307/1935966 